\title{
The Productivity Paradox and the Australian Mining Boom and Bust
}

\author{
Neil Dias Karunaratne ${ }^{1}$ \\ ${ }^{1}$ The University of Queensland, Brisbane, Qld. 4072, Australia \\ Correspondence: Neil Dias Karunaratne, Associate Professor, The University of Queensland, Brisbane, Qld. 4072, \\ Australia. Tel: 617-3878-1648. E-mail: n.karunaratne@uq.edu.au \\ Received: October 1, 2014 \\ Accepted: October 27, 2014 \\ Online Published: January 4, 2015 \\ doi:10.5430/rwe.v6n1p1 \\ URL: http://dx.doi.org/10.5430/rwe.v6n1p1
}

\begin{abstract}
Australia in the 1990s experienced a surge in multifactor productivity ushering in the 'golden age' of productivity. The subsequent 2000 decade witnessed a dramatic slump in productivity whilst the economy was riding the crest of the biggest terms- of- trade boom in its recorded history. This plummeting productivity occurring with a mining boom was a paradox. It created much concern and politicians and policymakers call for urgent action to reverse the productivity slump as it posed a threat to long-term growth and living standards of Australians. Much of the debate about the productivity paradox was due to the failure to grasp the phase-wise dynamics of the mining industry investment production cycle which operated with long leads and lags in attaining full capacity production. The paper uses a number of econometric techniques such as multivariate filters, the production function and state space methodology to empirically analyse the occurrence of the productivity paradox and the productivity slump. Thereafter the 'triangle model' a version, of the New Keynesian Phillips curve is used to review how the Reserve Bank of Australia (RBA) implemented monetary policy to keep inflation within the target zone whilst the economy was traversing the cusp of the biggest terms-of-trade boom in its recorded history, whilst facing the challenges 'Dutch disease' and deindustrialization.
\end{abstract}

Keywords: mining boom, productivity paradox, state space modelling, new Keynesian Phillips Curve, Dutch disease

\section{Introduction}

Productivity is a measure of how efficiently a nation uses its resources to produce goods and services for consumption. Productivity in an economy can be measured using a partial measure such as labour productivity, which is the ratio of output per hour worked or as a measure of multifactor productivity, which is the ratio of output per input of all factor inputs. Productivity is widely acknowledged as the crucial determinant of a nation's prosperity and is a measure of the living standards of its citizens. The importance of productivity has been highlighted by some quotes by some doyens of economics as follows: "Productivity isn't everything, but in the long run it's nearly everything' (Krugman 1994). "Productivity is the prime determinant in the long run of a nation's living standard" (Porter 1991).

In this paper we analyse trends in the growth of Australia's multifactor productivity (MFP ) which is also synonymous with the concept of total factor productivity (TFP) in order to examine the recent trend behaviour of Australia's productivity growth during the past three and half decades (1965-2010). The decade-wise analysis of productivity trend has witnessed a productivity surge culminating in the so called "golden age" of Australian productivity in the decade of the 1990s followed by decade of plummeting productivity in the 2000 decade. Around 2007 there emerged a phenomenon that has been dubbed the "productivity paradox" because of the coexistence of plummeting productivity and robust GDP growth. The nose-dive in productivity in recent 2000 decade has created widespread consternation both amongst policymakers and politicians. This consternation led to the appointment of a landmark Inquiry aimed at the identification of the underlying causes of the productivity paradox so that policies could be implemented to reverse the productivity slump that threatened Australian living standards (The Parliamentary Inquiry 2010).

Some of the driving forces leading to the ushering of the 'golden age' of Australian productivity in the 1990s decade have been attributed to the implementation of an agenda of micro-economic reforms in the mid-1980s releasing the Australian from the shackles of the 'Federation 'tri-fecta' which included protection, white Australian immigration and centralized wage-fixing. The implementation of the microeconomic reform agenda resulted in trade liberalisation, financial deregulation, labour market reform and the promotion national competitive policy. The implementation of microeconomic reforms also facilitated the emergence of the 'new economy' in the 1990s decade 
leading to the widespread adoption of the information communication technology (ICT) and robotics across industries and ushering the 'golden age' of productivity in the 1990s decade. Sceptics have dismissed the 'golden age' and the productivity paradox phenomena as statistical artefacts created by the mismeasurement of labour saving employment that occurs during economic downturns. In the subsequent 2000 decade there was dramatic slump in productivity despite the robust growth of the economy powered by the mining boom. The slump in productivity posed a threat to future growth and living standards and generated much public concern highlighting the need to implement policies to steer the economy out of the throes of the global financial crisis on to a locus of sustainable economic growth. ii. Tackle the burgeoning fiscal deficit and mounting debt required to meet the needs of a rapidly an ageing population. iii. Tackle the effects of global warming by implementing carbon emission trading and renewable energy supply schemes. iv Harness the terms of trade bonanza arising out of the mineral exports boom by channelling it to futures fund without frittering away in fiscal profligacy as in the past episodes of mineral export booms in Australia.

The major motivation of the paper arises out of the need to shed light on the trend behaviour of Australia's productivity growth in order to explain the key forces that lurk behind the productivity paradox and the recent dramatic slump in multifactor productivity (MFP) whilst the economy was on the cusp of the biggest terms-of-trade boom in its recorded history. In order to address this task, we have applied empirical techniques to Australian time-series data on multifactor productivity (MFP), real gross domestic product (GDP), terms of trade (TOT), unemployment rate $(\mathrm{u})$, inflation rate $(\pi)$ covering the study period (1965-2010) collected from official sources such as the Australian Bureau of Statistics (ABS) and the Reserve Bank of Australia (RBA).

The rest of the paper is organised as follows. Section 2 presents a brief explanation of the productivity paradox, where a productivity slump occurs whilst the economy experiences a record rise in the terms-of-trade powered by a mining export boom to mega-Asia. Section 3 outlines the econometric methodologies such as univariate filters, production functions and state space modelling deployed to shed light on stylised facts that underpin the emergence of productivity paradox. Section 4 reviews the major empirical findings of the study and concludes underscoring the need to design short-term stabilisation policies and long-term adjustment to prevent the benefits of the terms-of-trade boom from been frittered away in fiscal profligacy delivering a 'resource curse'. Section 5 concludes, outlining some of the policy challenges that confront the economy as it moves from the 'salad days' of the mining boom to the postmining-boom bust or the 'dog days'.

There is a copious research both in the international arena and in the Australian context explaining how resource booms have ended up as a resource curse, retarding the long-term growth performance of the economy after an initial brief spurt in growth. It has been demonstrated that the boom in the resource sector has crowded- out the dynamics of the manufacturing sector that operates as a country's engine of growth and innovation. This crowding- out dynamics of the resource boom leads to deindustrialisation and thereby undermines the long-term growth of the economy (Sachs J D and Warner A. M. 2001, Auty 2001). The recent literature surveys by Frankel 2010, Strum et al 2009) identify some of the causes of the emergence of the 'natural resource curse' as follows: i. High commodity price volatility resulting in income volatility resulting in low long-term growth. ii. Weakening of the democratic institutions and good governance due to rent-seeking and corruption. iii. Increase in pro-cyclical spending due to the pursuit of expansionary fiscal policies during resource booms. iv. Specialisation in the production in the natural resource sector leading to emasculation and crowding-out of other sectors resulting in unbalanced growth. iv. The appreciation of the exchange rate, rendering traditional exports uncompetitive leading to the emergence of "Dutch disease effects" and deindustrialisation.

The term 'Dutch disease' was coined by the Economist (1977) to describe the adverse effects on manufacturing exports due to the appreciation of the Dutch guilder caused by the boom in exports of North sea oil and gas. The occurrence of the "Dutch disease" phenomenon in Australia has been documented by (Gregory R G. 1976, Corden W M and Neary J P. 1982). Corden trichotomized the economy into a booming tradable sector (mining), a lagging trading sector (manufacturing) and a non-tradable sector (services). The resource boom sets in motion two effects described as a 'resource movement effect' and a 'spending effect'. The 'resource movement effect' pulls factors of production from the lagging tradable and nontradable sectors to the booming tradable sector (mining). The 'spending effect' occurs due to the extra income generated by the resource boom causing an increase in demand for nontradable sector output (services), thereby causing a detrimental effect on the lagging tradable sector (manufacturing) due to diversion of actors of production from it to the nontradable sector. The increase in demand for nontradables relative to tradables due to the spending effects of the resource boom causes price of nontradables to rise relative to tradables. This causes an appreciation of the real exchange rate leading to uncompetitiveness of traditional tradable exports (manufacturing) resulting in deindustrialisation and the emergence of a three-speed economy (Corden W.M. 2011).

Multifactor productivity is a crucial determinant of increasing potential output in an open economy such as Australia 
so that economic growth and living standards of Australians are preserved in the long-run when the economy is experiencing a mineral resource boom. These challenges facing policymakers are formidable and reiterated in the literature as follows: 1. The need to achieve sustainable growth in living standards without succumbing to the adverse "Dutch disease" and deindustrialisation effects that comes in train of a mineral resource boom. 2. The prevention of the 'overheating' of the economy because the unleashing of inflationary pressures due to the economy hitting capacity constraints or bottlenecks. 3 . The need to meet intergenerational fiscal challenges required to meet health and retirement income needs of a rapidly ageing population. 4 . The addressing of the issues of global warming and climate change by implementing policies directed at reducing carbon dioxide emissions. 5. The promotion of a speedy recovery from the effects of the global financial crisis and environmental hazards such recurrent floods, droughts and forest fires The Australian literature highlights that all these formidable policy challenges that confront the Australian economy have to be addressed in order to prevent the slump in productivity that emerged in the 2000 decade from undermining the growth and future prosperity of Australians as exemplified by (The Parliamentary Inquiry. 2010, Eslake S and Walsh M. 2011). Furthermore, surge in multifactor productivity in Australia in the 1990s responding to the microeconomic reform agenda implemented in the mid1980s resulted in an perceptible surge in trend growth of productivity in the mid-1990s, which has been dubbed the "golden age" of Australia's productivity by Dolman B. Parham D. Zheng S. 2007). The surge in multifactor productivity has been attributed to benign effects of a number of factors: A plausible explanation for the slump in productivity in 2000 decade relates to long lead times or gestation lags that transpire before mining projects reach full capacity. Therefore in the interim period as the project gears to reach full scale production productivity will be low ((Topp V Soames L Parnham D Bloch H. 2008). Microeconomic reform agenda that triggered the productivity surge encompassed trade liberalization, financial deregulation, and privatization of state enterprises, floating of the Australian dollar specifically entailing: 1. Trade liberalisation or the reduction protectionist trade barriers. 2. Microeconomic reforms that promoted competition in the product market and the labour market through Accords between employers and trade unions. 3. The adoption of new information and communication technology leading to the emergence of the 'new economy'. 4. Australia's catch-up with international productivity frontier or best-practice technology as proxied by the US production frontier (D'Arcy and Gustafsson 2012).

The dramatic slump in productivity in recent years has led to the emergence of a "productivity paradox" because the productivity slump occurred simultaneously with the robust growth in GNP due to the record boom in Australia's terms of trade in 2000 decade. Several conflicting explanations have been tendered to explain the emergence of the productivity paradox: 1 . It is argued that the productivity slump is due to the petering out of the salubrious effects of macroeconomic reforms undertaken during the mid-1980s. 2. The productivity slowdown is a trend decline in productivity independent of the cyclical downturn in productivity. 3. Others contend that the productivity slump is a figment of mis-measurement especially due to labour hoarding during recessions. 4. A plausible explanation blames the productivity slump on the gestation lags that are inherent in lumpy mining sector investments resulting in low productivity as the mining investment attains full capacity production. 5. Another explanation contends that the mining boom has made the economy hit 'capacity constraints' resulting in output exceeding potential and unemployment exceeding the natural rate thereby endangering stability of the economy due to the emergence of inflationary pressures (Stevens 2011).

The Phillips curve which postulated a short-term tradeoff between inflation and unemployment which was a centre-piece of Keynesian stabilisation policy had been declared as an 'empirical failure on a grand-scale' during the stagflation that occurred during the OPEC oil shocks in the 1970s (Lucas R E Jr and Sargent T 1978). The Phillips curve has been resurrected in the garb of the New Keynesian Phillips Curve (NKPC) and has become the intellectual framework that is used to design the stance of monetary policy by the RBA Gruen D Pagan A and Thompson C 1999). In this paper we use the NKPC framework and analyse on how the RBA has attempted to achieve the inflation target as the economy experiences the biggest terms-of-trade boom in its recorded history. The empirical analysis of forces driving the productivity paradox and the slump in productivity whilst riding the crest of the biggest ever mining boom in its history will provide invaluable information to design sound policies that will guide the Australian economy on to a path of sustainable long-term productivity growth that will increase living standards by avoiding the pitfalls of deindustrialization and Dutch disease that accompanies the aftermath of a mining boom.

\section{The Emergence of the Productivity Paradox}

Economic growth and prosperity of the Australian macro economy is inextricably tied up with the growth of multifactor productivity or the output generated by a unit of combined factor (labour and capital) inputs. Australia managed to avert a recession when other major economies went into a free fall during the recent global financial crisis (2007-08), mainly because of the robust record of productivity growth during the 1990s decade that eventuated because of the far-reaching microeconomic and macroeconomic reform agenda implemented in the 1980s, enhancing 
the international competitiveness of the Australian economy. The unusual coexistence of the slowdown in multifactor productivity and robust growth in real GDP has been referred to as the 'productivity paradox' and since the decline in productivity poses and ominous threat to the living standards and prosperity of the Australian populace policymakers have become aware of the need to address the fallout from the 'productivity paradox'. This adverse fallout from the productivity paradox is likely to become challenging because of so called 'Dutch-disease' or 'resource curse' effects.

Although the growth in Multifactor Productivity (MFP) (i.e. output per unit of capital and labour inputs which is a superior measure of productivity than the much used partial measure of labour productivity, which is based on output per labour input only) has remained steady during three productivity cycles from 1980s to mid-1990s, when it experienced a surge and then slowed down dramatically after 2003 registering negative growth rate. In Table 1 we report the decomposition of labour productivity (LP) in terms of multifactor productivity (MFP) and capital deepening or shallowing analysed using the Cobb-Douglas framework where

LP growth $=$ MFP growth + Capital deepening or shallowing effect. Treasury economists (Rahaman J Stephen D Tunny G. 2009, Ewing R. Fenner S. Kenndy S 2007) and the studies reported by the Productivity Commission (2004)and the estimates of multifactor productivity (MFP) published by the ABS (Australian Bureau of Statistics. 2012) provide information on the key drivers of Australia's productivity cycles and on the phenomenon of the 'productivity paradox' due to the growth real GNP powered by terms-of-trade boom coexisting with a slump in productivity. Both in the political arena and according to widely help public perception the slump in Australia's multifactor productivity growth posed a grave threat to Australia's growth and living standards and required urgent action to reverse the trends as highlighted in the Parliamentary Inquiry. 2010.

Stylised facts reported in Table 1, below show that Australia experienced a series of positive productivity growth cycles propelled by far-reaching microeconomic and macroeconomic reforms in the product, labour and financial markets since the beginning of the 1980s. In the mid-1990s Australia experienced a productivity resurgence that made Australia a frontrunner in the OECD productivity league. However, commencing in about 2000 the growth in Australian productivity trends has plummeted returning turning to negative MFP growth rate of $-0.3 \%$ in the last incomplete productivity cycle of 2003-2007. Table 1 also summarises the productivity cycles that occurred in Australia whilst the economy was transformed through the implementation of successive agendas of micro and macroeconomic reforms since 1981, whilst simultaneously facing exogenous shocks emanating from the global economy.

Table 1. Micro-economic reforms, growth rates, productivity cycles since 1981

\begin{tabular}{|c|c|c|c|c|c|c|c|}
\hline $\begin{array}{l}\text { Productivity } \\
\text { Cycle }\end{array}$ & $\begin{array}{l}\text { Growth } \\
\text { MFP } \\
\% \\
\end{array}$ & $\begin{array}{l}\text { Capital } \\
\text { Deepening } \\
\% \\
\end{array}$ & $\begin{array}{l}\text { Growth } \\
\text { LP } \\
\%\end{array}$ & $\begin{array}{l}\text { Growth } \\
\text { Real } \\
\text { GDP \% }\end{array}$ & $\begin{array}{l}\text { Key Microeconomic } \\
\text { Reforms }\end{array}$ & $\begin{array}{l}\text { Key Macroeconomic } \\
\text { Reforms }\end{array}$ & $\begin{array}{l}\text { Other Features } \\
\text { Of the Cycle }\end{array}$ \\
\hline $\begin{array}{l}1981-82 \text { to } \\
1984-85\end{array}$ & 1.1 & 1.2 & 2.3 & 2.6 & $\begin{array}{l}\text { Financial } \\
\text { Deregulation ' } 83\end{array}$ & $\begin{array}{l}\text { AUD Float 12/83. } \\
\text { Accord I 2/83 }\end{array}$ & $\begin{array}{l}\text { Mining boom I } \\
\text { Recession }\end{array}$ \\
\hline $\begin{array}{l}1984-85 \text { to } \\
1988-89\end{array}$ & 0.8 & 0.2 & 1.2 & 4.1 & $\begin{array}{l}\text { Foreign banks'87 } \\
\text { Export surge } \\
\text { Award restructure leading wage } \\
\text { rises }\end{array}$ & $\begin{array}{l}\text { Accord III } 2 / 87 \\
\text { Efficiency offset } \\
\text { to wages rises }\end{array}$ & $\begin{array}{l}\text { Wall Street Crash } \\
\text { Oct. } 1987\end{array}$ \\
\hline $\begin{array}{l}1988-89 \text { to } \\
1993-94\end{array}$ & 1.0 & 1.2 & 2.2 & 3.5 & $\begin{array}{l}\text { Tariff-cuts 88-91, Quota/subsidy } \\
\text { cut } \\
\text { Enterprise bargaining, } \\
\text { wage-moderation } \\
\text { (Accord VII 1991) }\end{array}$ & $\begin{array}{l}\text { Compulsory superannuation. } \\
\text { Accord VII } 1991\end{array}$ & $\begin{array}{l}\text { Recession } \\
1990-92 \\
\text { Immigration }\end{array}$ \\
\hline $\begin{array}{l}1993-94 \text { to } \\
1998-99\end{array}$ & 2.3 & 1.0 & 3.3 & 4.0 & $\begin{array}{l}\text { Tariff-cuts Nov. '98 } \\
\text { National Competition Policy }\end{array}$ & & $\begin{array}{l}\text { Asian Crisis '97 } \\
\text { Service sector } \\
\text { China's growth }\end{array}$ \\
\hline $\begin{array}{l}1998-99 \text { to } \\
2003-04\end{array}$ & 1.1 & 1.1 & 2.2 & 4.3 & Goods and Services Tax (2000) & Goods \& Services Tax 2000 & \\
\hline $\begin{array}{l}2003-04 \text { to } \\
2007-08 \\
\text { (Incomplete) }\end{array}$ & -0.3 & 1.4 & 1.1 & 5.0 & & Work choices 2006 & \\
\hline
\end{tabular}

Sources: Commonwealth of Australia (2010) Inquiry into Raising Productivity Growth rates in the Australian economy. ABS Australian System of National Accounts. Cat. 5204.0,2007-08, RBA Statistical Tables. 
The Australian MFP series compiled by the ABS has been analysed in this paper. Among the most salient features are the stylised facts reported in Figure 1 relating to the level and growth rate of MFP reveal that a productivity slowdowns occurred after the "oil price" shocks in 1973 and 1979. However, soon after MFP appears to have reverted to its trend and potential growth rates. Around 1995 after the widespread adoption information technology and robotics Australia heralded in the "new economy" causing an upward shift in both the level and potential growth rate. In order to analyse the trends in MFP growth it is necessary to remove cyclical effects as MFP moves procyclically registering a surge in growth during booms and declines in growth during slumps.

A major aim of this paper is to analyse both the trend or the level and the growth rate of potential output, MFP, GDP, UNE during the study period 1965-2010 in using rigorous analytical techniques in order to clarify the behaviour of these key macroeconomic variables and dispel some of obfuscations that have led to call for populist policies to reverse the productivity slump. In the next section we present the econometric methodologies that shed light on trend productivity growth and productivity cycles that occurred during the study period. Thereafter, we examine how monetary policy coped with inflation targeting in an economy experiencing a mining boom.

\section{Econometric Methodology}

In the paper three major econometric techniques have been used to analyse the trend or potential level of MFP and GDP over the study period 1965-2010. The three techniques used are: i. Statistical Filters (such as the Hordrick-Prescott or HP-Filter).

ii. Production Functions (such as the Cobb-Douglas Production used in Solow growth accounting). iii. State Space analysis (which involves the estimation of unobserved components using the recursive algorithm known as the Kalman Filter (KF). (Harvey A.C. 1989)

The first technique, the HP-filter is a univariate detrending method which estimates the trend or potential of MFP or GDP using a purely statistical formula devised by (Hordrick R.J. and Prescott. E.C. 1997). It computes the trend of variable by minimizing the weighted sum of squared deviation of the variable from its potential value plus the growth rate of the squared deviation from its potential. The smoothness of the trend or potential increases as the weight or the smoothing parameter $\lambda$, which is also a measure of the signal-to-noise ratio decreases. In this paper we have used a smoothing parameter of and its modification known as the Gordon filter ((Gorden R J. 2003)) based on smoothing parameter $\lambda=32$ rather than $\lambda=1600$ as used by Hordrick and Prescott for detrending quarterly data. The algebraic specification of the HP Filter is given in Note 1. for analysing quarterly time-series. Besides the HP- filter there are several other univariate filters such as the Band-Pass-Filter due to Baxter and King) and the Beveridge-Nelson Decomposition have been used for detrending time-series ((Harvey A.C. 1989). All these univariate filters are purely statistical techniques devoid of any economic content. Some of the other Filters that have been used to estimate the stochastic trend of a given time-series.

The second econometric technique for measuring trends or potential MFP and GDP used in this paper, is based production functions and is grounded neoclassical theory of economic growth. We have used to the Cobb-Douglas production used in growth accounting where growth in output (GDP) is explained exogenous technological progress (MFP) and a weighted average of inputs of capital and labour (Solow R 1957). The Solow method based on the Cobb-Douglas production function is also based on a number of assumptions such as constant returns to scale, Hicks neutral technological change. However, because of strong economic foundations it has been widely used as the benchmark measure for estimating trends in MFP trends in potential GDP. The ABS has used, the Translog function, a variant of the neoclassical production function to estimate the MFP. Besides Translog function, the Constant Elasticity of Substitution (CES) production function has also been used to measure MFP and all these variants share the same advantages and limitations of the Cobb-Douglas production function which is explained in algebraic terms in Note 2.

The third technique that has been used for empirical analysis of trend or potential of MFP, GDP and their growth rates is based Space (SS) Modelling using the Kalman Filter to obtain maximum likelihood estimates of the unobserved components (UC) in a time-series. The Kalman Filter (KF) is a powerful recursive algorithm that has been used in control theory for tracking the landing of aircraft using radar, launching the Apollo missions and ballistic missiles. It is now gaining increasing popularity for the estimation of the unobserved components in structural time-series models with time-varying parameters. The KF algorithm is recursive algorithm that plays the same role in structural time-series modelling with time-varying parameters as the OLS technique in estimating fixed parameters in classical regression models. The KF algorithm is available in most computer programs that are used for structural time-series analysis such as EViews, Stata, RATS and STAMP. In this paper we have used the Structural Time Series Analyser Modeller and Predictor (STAMP 8.2) (Koopman S J Harvey A C Doornik J A and 
Shephard N. 2009) the estimation of the time-varying parameters related to unobserved trends and cycles in time-series of MFP, GDP, UNE, TOT, CPI analysed in this paper.

The SS modelling technique for the estimation of trends in MFP are based on structural time-series modelling with time-varying parameters as exposited in the contributions of (Harvey A.C. 1989, Durbin I and Koopman S J. 2001 and others). In the SS methodology the actual or observed value of a time-series variable is defined in terms of an observation equation which decomposes it into an unobserved stochastic trend and a random disturbance term that is white-noise or distributed independent normal with mean zero and constant standard deviation. Then the state of system is described by two state equations: the first of which defines the trend as a random walk with the disturbance term following an autoregressive process of order one or AR(1). The second, state equation defines the slope of the first state equation as a random walk autoregressive order two or AR(2) process and a white-noise disturbance term that is distributed independent normal with mean zero and constant variance.

An algebraic specification of the Local Linear Trend Model (LLTM) described above is presented below for the time-series on MFP or GDP represented by $\mathrm{y}_{\mathrm{t}}$. In the observation equation $\mathrm{y}_{\mathrm{t}}$. is decomposed into a trend or level component $\mu_{\mathrm{t}}$ and white-noise random disturbance term $\varepsilon_{\mathrm{t}}$ which is distributed independent normal with zero mean and constant variance $\sigma_{\varepsilon}^{2}$, over the sample period $\mathrm{t}=1, \ldots, \mathrm{T}$ :

$\mathrm{y}_{\mathrm{t}}=\mu_{\mathrm{t}}+\varepsilon_{\mathrm{t},} \quad \varepsilon_{\mathrm{t}} \sim \mathrm{NID}\left(0, \sigma_{\varepsilon}^{2}\right)$. Observation or signal equation

The two state or transition equations, one capturing the stochastic level and the other stochastic slope are specified below:

$\mu_{\mathrm{t}}=\mu_{\mathrm{t}-1}+\beta_{\mathrm{t}-1}+\eta_{\mathrm{t}} \quad \eta_{\mathrm{t}} \sim \operatorname{NID}\left(0, \sigma_{\eta}^{2}\right)$. State equation on the level

$\beta_{\mathrm{t}}=\beta_{\mathrm{t}-1}+\zeta_{\mathrm{t}} \quad \zeta_{\mathrm{t}} \sim \mathrm{NID}\left(0, \sigma_{\zeta}^{2}\right)$. State equation on the slope

where $\eta_{\mathrm{t}}$ and $\zeta_{\mathrm{t}}$ white noise disturbance terms of the above state equations that are distributed normally, independent of each other, with zero mean and constant variances, $\sigma_{\eta}^{2}$ and $\sigma_{\zeta}^{2}$. In the first state equation, the disturbance term $\eta_{\mathrm{t}}$ explains the shifts in the trend or level $\mu_{\mathrm{t}}$. While in the second state equation the disturbance term $\zeta_{\mathrm{t}}$ explains the

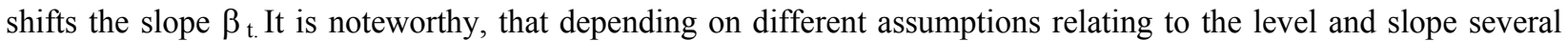
variants of the local linear trend model are nested in the above specification as tabulated below:

\begin{tabular}{lll}
\hline Type of Model & Level $\left(\mu_{t}\right)$ & Slope $\left(\beta_{t}\right)$ \\
\hline 1.Random Walk + Noise & Stochastic & No Slope $\left(\beta_{t}=0\right)$ \\
\hline 2.Local Level + Drift & Stochastic & Slope fixed. \\
\hline 3.Smooth Trend & Fixed & Slope Stochastic \\
\hline 4. Basic Structural Model $(B S M)$ & Fixed & Slope Stochastic
\end{tabular}

The maximum likelihood estimates of the parameters of any of the structural time-series models specified above can be estimated by the recursive algorithm, the Kalman Filter (KF). The KF estimates time-varying parameters in structural time-series models just like the estimation of fixed regression parameters by the OLS method. KF algorithm can provide both filtered estimates of the parameters of the state equations of the structural time-series models using the last period's best estimate of trend growth or smoothed estimates of the time-varying parameters based on the full sample of observations covering the entire sample period. The process of obtaining smooth estimates is also referred to as signal extraction. Signal extraction is quantified by the ratio of the variances of the disturbance terms of the state equations defined by the parameter $\lambda=\sigma_{\eta}{ }_{\eta} / \sigma_{\varepsilon}{ }_{\varepsilon}$. The application of the KF requires that the observation and state equations should be transformed into the State Space Form (SSF) as outlined in Note 3.

The major causes that explain the emergence of the 'productivity paradox' and the plummeting MFP despite record rise in the terms-of-trade bolstering GDP growth 2000 decade in the study period (1965-2010) is analysed empirically using the local linear trend model (LLTM). specified below. The explanatory variable ( $\mathrm{x}_{\mathrm{t}}$ ) proxies variables such as MFP or GDP, whilst random-walk trend (level) is proxied by $\mu_{\mathrm{t}}$ and an irregular and intervention variable $\mathrm{w}_{\mathrm{t}}=\mathrm{TOT}_{\mathrm{t}}$ captures the terms-of-trade boom effect on $\mathrm{MFP}_{\mathrm{t}}$ or GDP $\mathrm{G}_{\mathrm{t}}$. The empirical validation of the model 1 shed light on the productivity paradox and the slump that occurred during the 2000 decade and they are discussed in the next section.

$$
\begin{array}{ll}
y_{t}=\mu_{t}+\delta x_{t}+\lambda w_{t}+\varepsilon_{t}, & \varepsilon_{t} \sim N I D\left(0, \sigma_{\varepsilon}^{2}\right) \\
\mu_{t}=\mu_{t-1}+\theta z_{t}+\eta_{t}, & \eta_{t} \sim N I D\left(0, \sigma_{\varepsilon}^{2}\right)
\end{array}
$$

After empirically validating the Local Linear Trend Model, its statistical plausibility is verified by subjecting it to a battery of diagnostic tests relating to autocorrelation, heteroscedasticity or departures from normality and 
goodness-of--fit. These diagnostic tests are explained further in Note 4.

Cycle plus Trend model and Cyclic Trend Model

The local linear trend model (LLTM) could be augmented by a cyclical component $\left(\Psi_{\mathrm{t}}\right)$, which is a deterministic since-cosine wave leading the specification of the Cycle Trend Model given below:

$$
y_{t}=\mu_{t}+\Psi_{t}+\varepsilon_{t}, \quad \text { where } \varepsilon_{t} \sim \operatorname{NID}\left(0, / \sigma_{\varepsilon}^{2}\right), t=1, \ldots, T \text {. }
$$

The cycle $\Psi_{\mathrm{t}}$ is both a function of time (t) and the parameter $\lambda_{\mathrm{c}}$ which defines the frequency of the cycle measured in

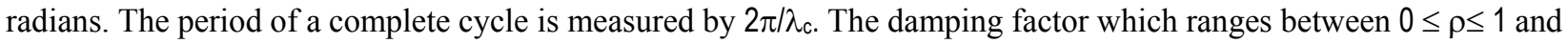
the white-noise disturbance terms $\kappa_{t}$ and $\kappa_{t}^{*}$ enables the full specification of the cycle plus trend model: A deterministic cycle i.e. a sine-cosine wave $\left(\psi_{\mathrm{t}}\right)$ with a given period could be incorporated in the trend equation for the series $\mathrm{y}_{\mathrm{t}}$ it could be rendered stochastic by shocking it with a disturbance and introducing a damping factor giving the statistical specification of the cycle plus noise model :

Multivariate or the joint modelling of TFP and GDP can also be used to determine whether these two series which are integrated random walks and therefore cointegrated. If they are cointegrated then it supports the contention of Real Business Cycle (RBC) theorists proposition, that short-term business cycle fluctuations are caused by technological shocks and therefore activist Keynesian type of monetary stabilization policies are superfluous (Kydland FE and Prescott EC. 1982). However, the New Keynesians contend that in the short-run, sticky wages and prices prevail because nominal price and wage rigidities. Therefore the RBC theory of a frictionless market where monetary policy has no short-term stabilization role is disputed. In fact the current consensus as that propounded by the New Keynesian theories that monetary policy has a vital role to play in the short-run because the prevalence of nominal and real wage price rigidities (Clarida R Gali J and Gertler M. 1999). In this paper we have empirically validated a version of the New Keynesian Phillips Curve (NKPC) based on the 'triangle model' (Gordon, RJ 1997) to empirically examine how the RBA implemented stabilization policies to keep inflation within the 'target-zone' when the economy was experiencing the golden age of productivity in the 1990s and exhibiting the productivity paradox where productivity was plummeting whilst having a sky-rocketing terms -of- trade. The empirical results relating to the RBC theories and the 'triangular model' based on the New Keynesian Phillips Curve (NKPC) that shed light on the implementation of stabilization policies to keep inflation within the target zone during the mining boom are discussed in the next section.

\section{Empirical Results}

In this section we discuss some of the empirical findings from the validation of the LLTM that shed light on the Australia's trend growth rate in MFP leading to the ushering of the 'golden age' of high productivity in the 1990s and its slump in the 2000 decade starting about 2003. These results are devoid of any business cycle effects. If MFP is at its trend or potential, then output is also at the trend level or potential level and factors or production in the economy are used efficiently to produce the maximal output in order to achieve the goals of the triple mandate of full employment, low inflation and sustainable growth rate of a modern central bank.

The deviation of output from potential or trend output that measures the output gap occurs because MFP is not at its potential and if the output gap is positive then because the actual output exceeds potential output it could generate inflationary pressures, requiting the central bank to adopt a contractionary monetary policy stance to keep inflation within the mandated target zone. If the output gap is negative labour and product markets are in slack and expansionary monetary policies are in order to achieve potential output or capacity production. Potential output and therefore output gap are metrics of crucial interest to policymakers. However, there are unobservable and they can be estimated using state space (SS) methodology that uses the recursive numerical optimization algorithm, the Kalman Filter for the purpose.

In this section we present the empirical results based on the application of the SS econometric techniques to Australian time-series data on MFP, GDP, TOT, CPI \& UNE sourced from ABS, RBA and other official sources. By the empirical validation of variants of the SS models we estimate the level of trend and the growth rate of trend of MFP and GDP using the local level or random walk plus noise model, the local level with drift, smooth trend, and the basic structural time-series model. We also report the goodness of fit of the models using a battery of diagnostic and goodness-fit tests. The empirical validation of the equations of the Local Level Linear Trend Model(LLTM) are reported in Table 2 and in graphs relating to level and trend growth rates are reported in in Figure 1 \& Figure 2 below: 
Table 2. Trends \& growth rates - local level model estimated using the Kalman Filter

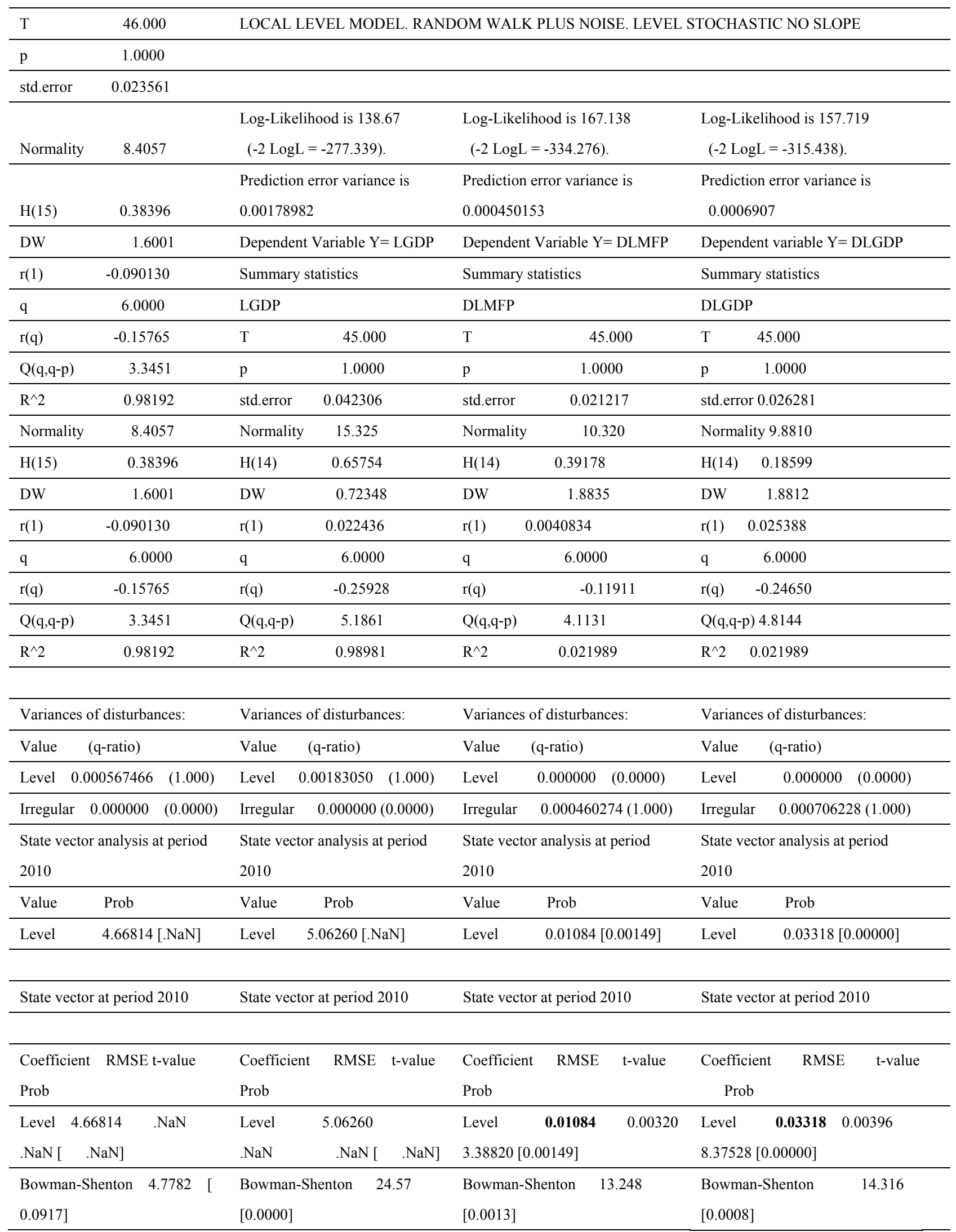




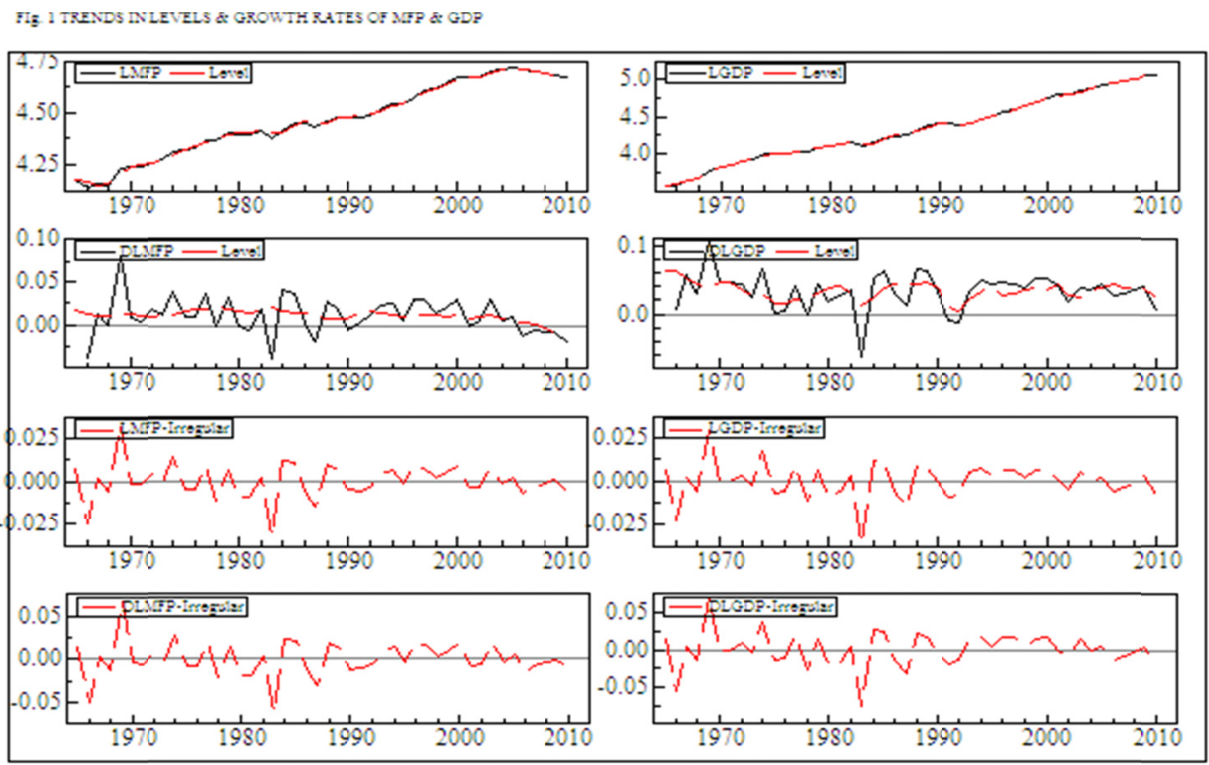

Figure 1. Trends in levels \& growth rates of MFP \& GDP

The results indicate that during the study period (1965-2010) the trend growth rate of MFP was 1.08 per cent p.a. and that of GDP growth rate was much more robust 3.31 per cent p.a. The MFP growth rate graphs in Figure 1 reveal that the growth rate of MFP (DLMFP) surged during the 1990s supporting the claim that 1990s was the "golden age" Australian productivity. Then, during the 2000 decade, starting around 2003 the trend growth rate productivity started to plummeted. This slump in productivity occurred pari passu whilst the trend growth rate of GDP (DLGP) increased at a robust pace. The plummeting productivity growth rate whilst GDP growth rate increased lends credence to the claim of the emergence of a 'Productivity Paradox' (PP). The graphics also illustrate that towards the tail-end of the study period around 2008 the MFP growth rate began a precipitous nose-drive heightening the concerns of policymakers and politicians that urgent policy action was needed to reverse the plummeting MFP in order to avoid threat to Australia's long-term growth and prosperity. This led to the appointment of the land mark Parliamentary Inquiry (2010) to take urgent policy action to counter-act the productivity slump.

Furthermore, the residual graphics on MFP and GDP trends and growth reported in Figure 2 confirm the trend levels and growth rates were not the upshot of cyclic effects. The correlograms (ACF graphics) indicate very low serial correlation indicating the virtual absence of cyclical effects and this inference is further supported by the graphics of the spectral density function.

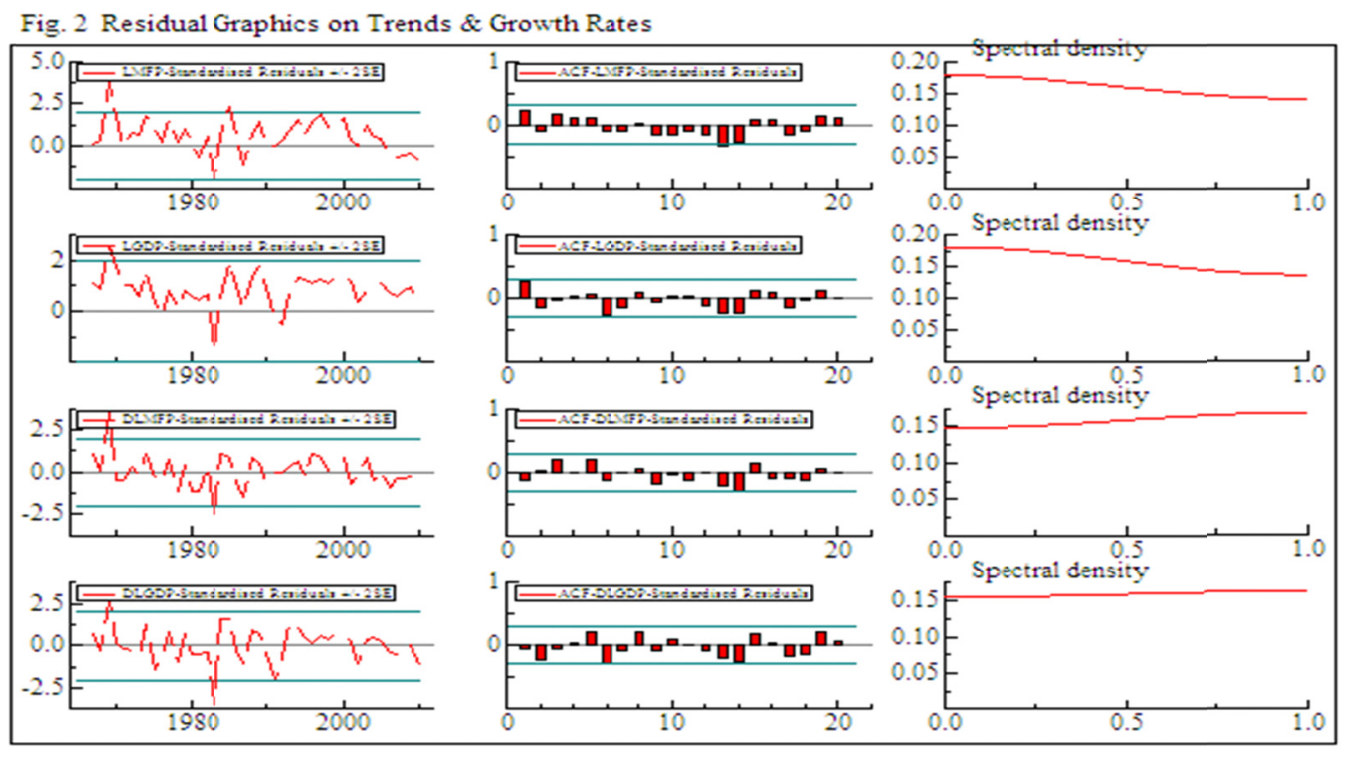

Figure 2. Residual graphics on trends \& growth rates 
The concerns about the deleterious effects of the productivity paradox and productivity slump were misplaced and arose from the failure to understand the phase-wise development of the mining product cycle. In the 2000 decade the mineral resource boom had led to massive inflow of lumpy foreign investment to the mining sector. During the investment phase of the mining industry which occurred in the 2000 decade due to long lead times required to attain capacity production productivity is bound to be low. However, as the mining sector transcends to the full capacity production phase productivity is bound to pick-up. The failure to grasp the phase-wise dynamics inherent in the mining product cycle where investment phase has low productivity due to long lead times required to reach the capacity production phase with full productivity undoubtedly obfuscated the public debate productivity paradox and may have led to a policy overkill because of the failure to grasp the phase-wise dynamics resulting in the long leads and lags inherent in mining investment and production cycle.

Cycle plus Trend \& Trend-Cycle Model empirics

The empirical results of the local level or random walk plus noise model and the graphics confirm that cyclical factors buried in the noise had no bearing whatsoever on the trend behaviour. Fitting a Trend plus Cycle Model to LMFP and LGDP series confirm that the deterministic business cycle had no affect on the trend of the above two series obtained from the fit of the local level with fixed level and no slope in the graphs in Figure 3 report that a small cycle with a period of 2 years and a medium cycle with a period of 20.4 years appear to fit the time-series of LGDP and LMFP.

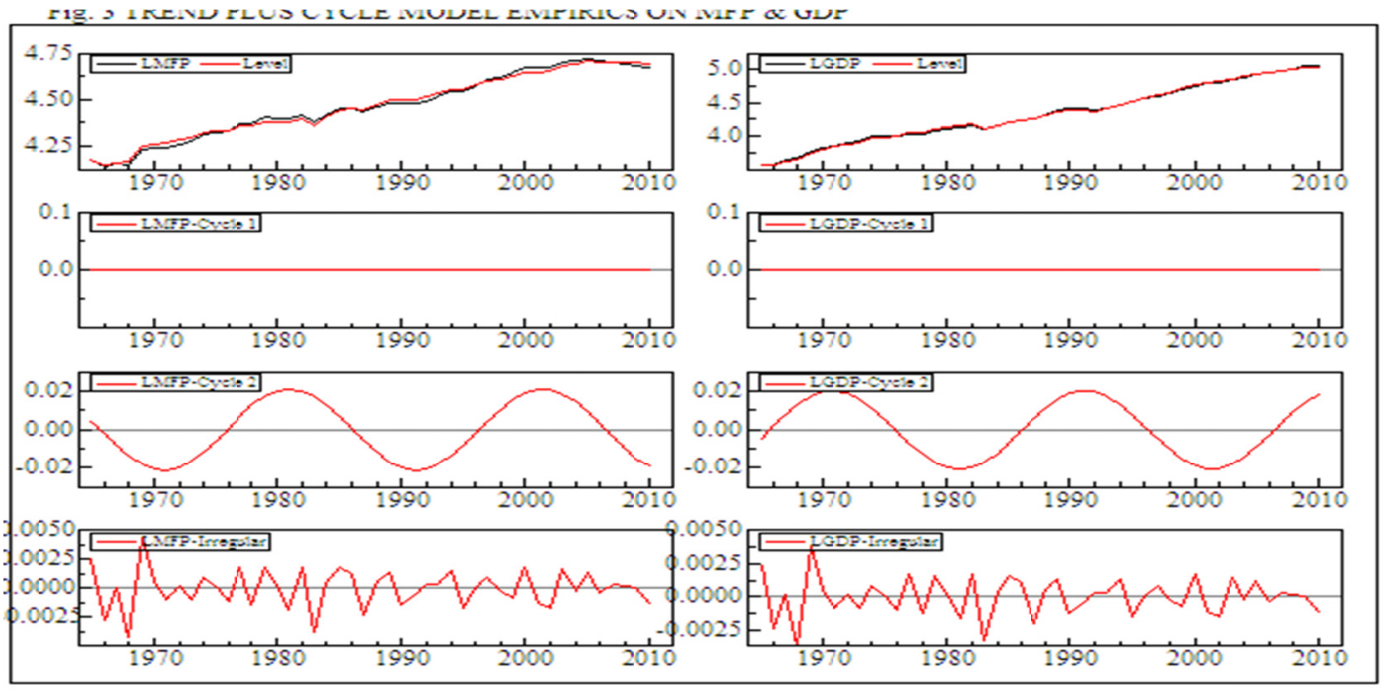

Figure 3. Trend plus cycle model empirics on MFP \& GDP

The fitting of the Trend-Cycle Model estimating LGDP and LMFP jointly, assuming a $4^{\text {th }}$ order cycle reveals that the two series with balanced slopes are highly correlated.

Table 3. Intervention analysis of the effects of the TOT boom on LMFP, LGDP \& UNE

\begin{tabular}{lccc}
\hline Regression effects in final state at time 2010 & & \\
\hline Coefficient & RMSE & t-value & Prob \\
\hline LGDP(DEPVAR) & & & \\
\hline LMFP & -3.35924 & 6.51268 & $-0.51580[0.60870]$ \\
\hline LTOT & $5.31686^{* *}$ & 2.40926 & $2.20684[0.03284]$ \\
\hline LMFP(DEPVAR) & & & $12.25936[0.00000]$ \\
\hline LGDP & $0.7254^{* *}$ & 0.05917 & $-2.37115[0.02240]$ \\
\hline LTOT & $-0.07171^{* *}$ & 0.03024 & \\
\hline UNE(DEPVAR) & & & $-0.51580[0.60870]$ \\
\hline LMFP & -3.35924 & 6.51268 & $2.20684[0.03284]$ \\
\hline LTOT & $5.31686^{* *}$ & 2.40926 & \\
\hline LMFPDEPVAR & & & $-1.77346[0.08340]$ \\
\hline UNE & $-0.00531^{*}$ & 0.00300 & $0.27977[0.78102]$ \\
\hline LTOT & 0.01440 & 0.05146 & \\
\hline
\end{tabular}

${ }^{* *}$ Significant at $1 \%$ level, ${ }^{*}$ Significant at $5 \%$ level. 
The equations have passed a battery of diagnostic tests \& goodness-fit-criteria.

The intervention empirics on the TOT boom reported in Table 4 indicate that the TOT increase had significant positive effects on LGDP whilst at the same time it had a negative effect on LMFP. This simultaneous occurrence of positive income or GDP effects and negative MFP effects give credence to existence of a Productivity Paradox in

The 'smoking gun' behind the productivity paradox (PP) associated with mining boom related to a number of causes such as the high prices commanded by mineral exports causing massive investments in the mining sector, The increase in lumpy capital inputs with gestation lags of around five years results in the increase in a capital shallowing effect or the decrease in capital per worker reducing labour productivity and have adverse effects on MFP as shown in by an in-depth shift-share analysis over several sectors. Based on the Cobb-Douglas production function we can derive the following relationship:

Labour productivity growth $=$ MFP growth + Capital deepening/ shallowing effect.

There is overwhelming empirical evidence that the TOT boom and interacting with the mining sector was the cause of the MFP productivity slowdown and the PP paradox that has occurred during the 2000 decade of the study period. While appropriate structural adjustment policies need to be implemented to prevent the resource boom from turning into a resource curse in the long-run, in the short-run policymakers also have to grapple with the challenge of implementing stabilizing monetary policy to keep the economy on a sustainable growth locus without being knocked -off course by inflationary pressures. Next, we undertake an empirical analysis of stylised facts that will shed light on how the Australian policymakers may face the challenges of inflationary pressures unleashed by the TOT boom, given the policy commitment to the institutional framework of inflation targeting with Central Bank Independence.

Empirics of the Output gap and Unemployment Gap and Productivity

The estimates of potential output and full employment level of unemployment or the non-accelerating rate of unemployment (NAIRU) estimates using the univariate, filters lack economic content. Therefore, in order to analyse the effects of the cyclic position of the economy as measured by the potential output we use the modern expectations augmented Phillips curve as presented in the' 'triangular model' of inflation popularised by (Gorden R J. 2003)). The triangle model postulates that the inflation rate $(\pi)$ depends on three forces: expected inflation $\left(\pi^{\mathrm{e}}\right)$, deviation of unemployment rate from the natural rate or NAIRU $\left(u-u^{*}\right)$ indicating the cyclical position of the economy and supply $\operatorname{shocks}(v)$ :

$\pi=\pi^{\mathrm{e}}-\beta\left(u-u^{*}\right)+v=\pi^{\mathrm{e}}--(1 / \alpha)\left(y-y^{*}\right)+v$

The triangle model of the Phillips Curve

Using the Okun's Law (Okun A M. 1962) which postulates a relationship between the unemployment gap or the deviation of unemployment from potential i.e. ugap $=\left(u-u^{*}\right)$ and the output gap or deviation of output from potential $\left(\mathrm{y}-\mathrm{y}^{*}\right)$ giving:

$\beta\left(u-u^{*}\right)=-(1 / \alpha)\left(y-y^{*}\right)$

Okun's law

the triangle model of the Phillips curve could be re-written by substituting the out gap for the unemployment gap. The resulting Phillips curve predicts that inflation exceeds expected inflation when output exceeds potential output. Potential output $\left(\mathrm{y}^{*}\right)$ could be estimated using the univariate HP filter (Hordrick R.J. and Prescott. E.C. 1997). The stylised facts from the expectations augmented Phillips curve or the triangle model could incorporate inflation targeting to keep inflation within a prescribed target zone.

Using time-series data, we have estimated a Phillips curve assuming perfect expectations and Okun's equation. The results are reported in Table 4.

Table 4. The Phillips Curve and Okun's Equation (1965-2010)

Estimation done by Maximum Liklihood Exact Score

\begin{tabular}{|c|c|c|c|}
\hline \multicolumn{2}{|c|}{ Phillips Curve } & \multicolumn{2}{|c|}{ Okun's Law } \\
\hline \multicolumn{2}{|c|}{ Log-Likelihood is $157.96(-2 \log \mathrm{L}=-315.921)$} & \multicolumn{2}{|c|}{ Log-Likelihood is $79.1234(-2 \log \mathrm{L}=-158.247)$} \\
\hline \multicolumn{2}{|c|}{ Prediction error variance is 0.000378737} & \multicolumn{2}{|c|}{ Prediction error variance is 0.0181875} \\
\hline \multicolumn{2}{|c|}{ Summary statistics } & \multicolumn{2}{|c|}{ Summary statistics } \\
\hline \multicolumn{2}{|l|}{ DLCPI } & \multicolumn{2}{|l|}{ Ugap } \\
\hline $\mathrm{T}$ & 44.000 & $\mathrm{~T}$ & 45.000 \\
\hline $\mathrm{p}$ & 4.0000 & $\mathrm{p}$ & 5.0000 \\
\hline std.error & 0.019461 & std.error & 0.13486 \\
\hline Normality & 2.7502 & Normality & 11.275 \\
\hline
\end{tabular}




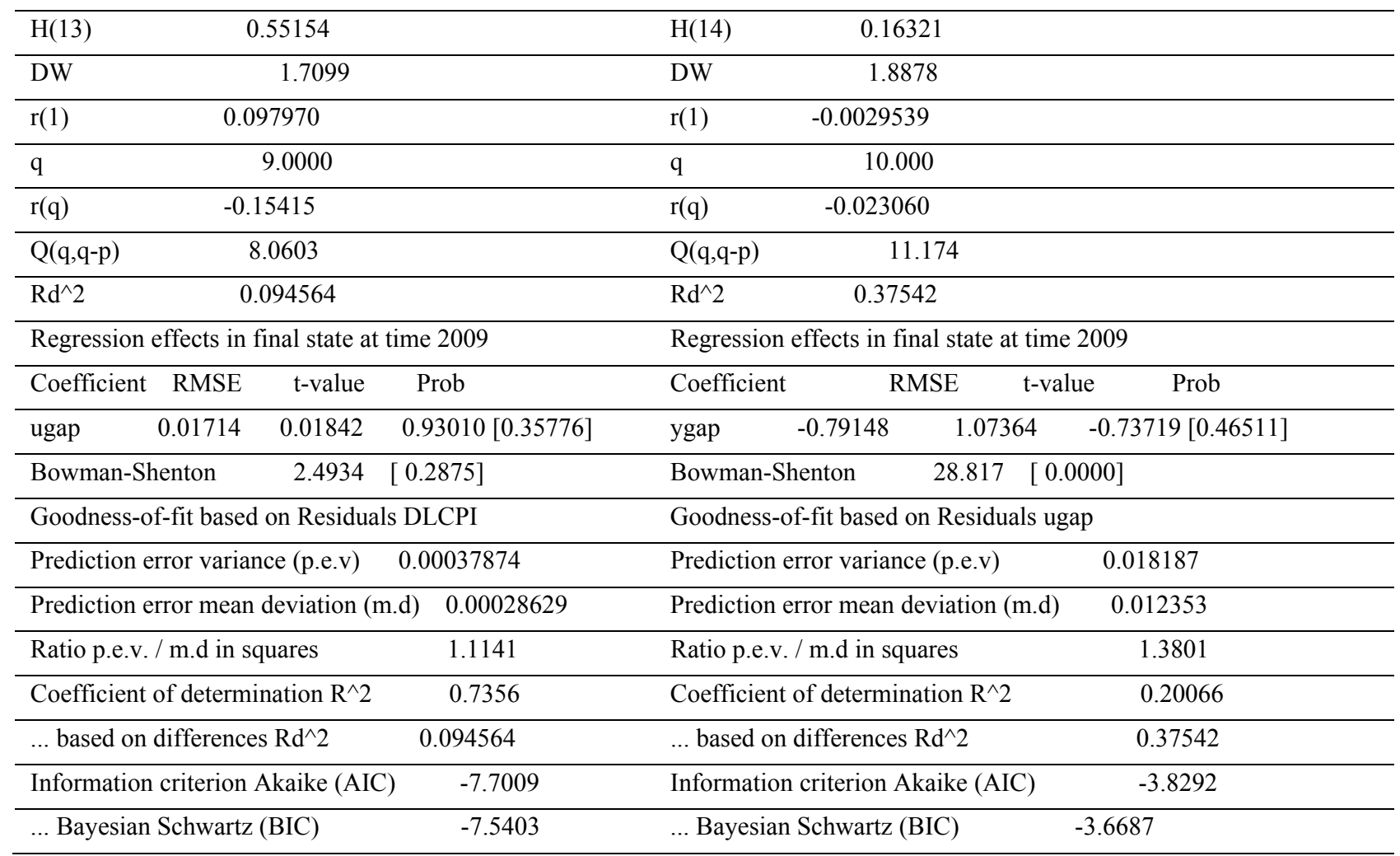

The no frills Phillips curve indicates that an increase in the output gap (ygap) by 1\% increases inflation by approximately $0.02 \%$ during the study period, this is consistent with the findings of de Brouwer $\mathrm{G}$ and Ericsson $\mathrm{N}$. 1998. The no frills Phillips curve which glosses over the inflationary expectations process gives estimates that do not deviate that much from the expectations augmented Phillips curve estimated for Australia estimated by Debelle G and Vickery J. (1998). The Debelle-Vickery estimates of the expectations augmented Phillips curve indicates that a $1 \%$ positive output gap will cause inflation to be above expected inflation $0.07 \%$, higher than the no frills Phillips curve estimate of de Brouwer.

The estimate of the Okun coefficient indicates that an increase in the output gap for the study period investigated the unemployment rate is below NAIRU indicating that $1 \%$ increase in the output gap would cause the unemployment gap to decrease by $0.79 \%$. The figure for unemployment increase reported by de Brouwer using NAIRU estimates is higher than that reported by Debelle and Vickery.

Both the Phillips curve and Okun's Law indicate that Australia in 2009 had reached 'capacity constraints' as output exceeded potential or output gap was positive implying that the economy was facing inflationary pressures. Furthermore, the unemployment rate was below NAIRU indicating that Australia's unemployment rate of $\mathrm{u}^{*}=4.3 \%$ was below NAIRU or the long-term average of $u^{*}=5 \%$. The possibility of the economy overheating as the economy hit capacity constraints as the economy grew powered by the TOT boom associated with the increase in mineral resource exports to growing mega-Asian economies of China and India.

Furthermore the fit of the Trend-Cycle model to LGDP and LMFP revealed that the two series were highly correlated. The series are cointegrated of order $(2,1)$. Figure 4 givn below shows that the series do not have a single common trend and the role of the stochastic level LMFP equation is allow for changes in the long-run proportion of LGDP to be absorbed: LMFP. The cointegration between LGDP and LMFP lend credence to the RBC hypothesis that technological shocks are the sole cause of business cycle fluctuations thereby negating the need for stabilisation policies as advocated by Keynesian theories. In this context, we explored whether the MFP series and GDP series were co integrated, because if they were, this would lend support to the Real Business Cycle (RBC) theoretic prognostications that short-term business cycle fluctuations were caused by technological shocks (Kydland FE and Prescott EC. 1982). The co- integration results from the application of the Cyclic Trend Model to GDP and MFP also lend support to the RBC perspective that the short-run fluctuations of the Australian business cycle are caused by technological shocks as hypothesised by the proponents of RBC theory. The empirics of the Trend plus Cycle Models fitted to log of MFP (LMFP) and log GDP over the study period indicate that for LMFP a short cycle with a 
period of 2 years, a frequency of 3.14 with a damping factor of 0.99 and a medium cycle with a period 20.4 years, a frequency of 0.31 and a damping factor of 1.00 is buried in the noise in the Local Level Trend model fitted to the Australian time-series data on LMFP.

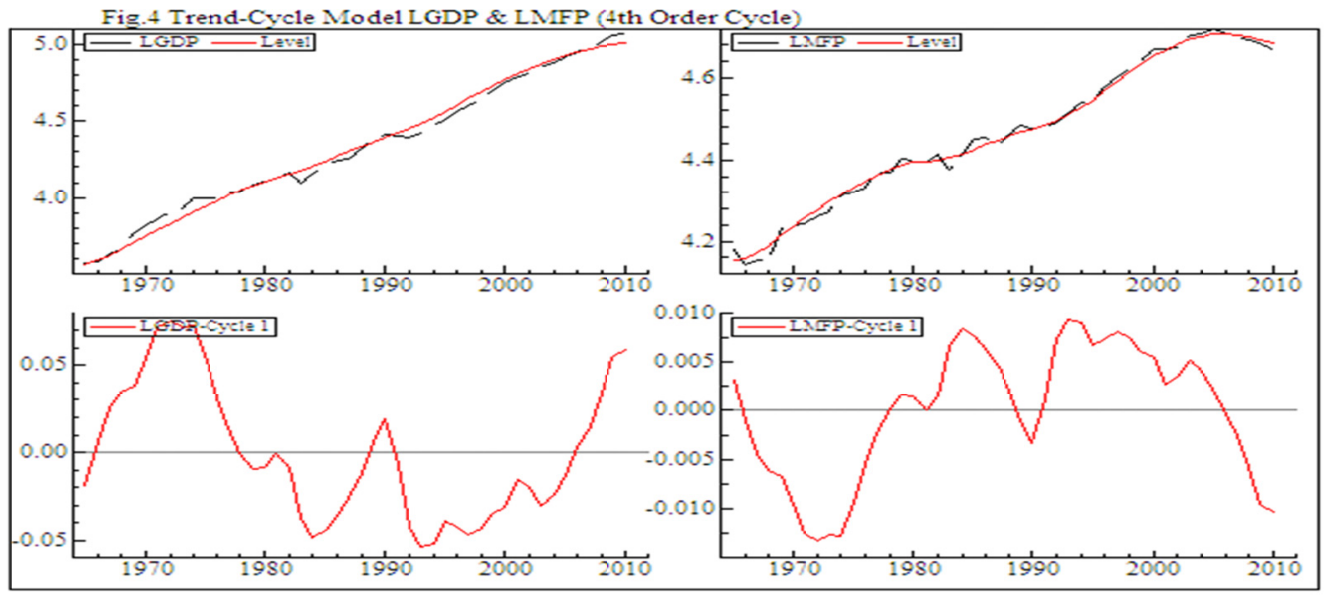

Figure 4. Trend-cycle model LGDP \& LMFP (4th order cycle)

Nevertheless, the New Keynesian theorists warn against the abandoning of discretionary and activist policies because of the existence of nominal price and labour market rigidities in the short-run cast doubts about the frictionless markets hypothesised by proponents of RBC theories (Gali J. and Gertler M. 1999).

The triangle model of the expectations augmented Phillips curve postulated by Gordon (Gordon R J. 1997) takes account of only backward looking inflation while the design of optimal monetary policy according to New Keynesian theory should take into account forward looking inflation. The New Keynesian Phillips Curve (NKPC) with forward looking expectations could be stylised as follows:

$$
\pi_{\mathrm{t}}=\alpha \mathrm{E} \pi_{\mathrm{t}+1}+\beta\left(Y_{\mathrm{t}}-\mathrm{Y}^{*}\right)+\varepsilon_{\mathrm{t}}
$$

where $\alpha$ and $\beta$ are constants, $\pi_{t}$ : inflation at time $t, E \pi_{t+1}$ : expectations of inflation at time $t+1, \varepsilon t$ : whiten noise error term.

The above NKPC is also consistent with the Hybrid NKPC postulated by Gali and Gertler (1999). The trend- cycle decomposition undertaken therein provides a parsimonious specification of the unobserved components of the hybrid NKPC (Harvey 2011). The NKPC is central to modelling monetary policy design using dynamic stochastic general equilibrium (DSGE) modelling as demonstrated in the research applications for the small open economy of Australia with incomplete exchange rate pass- through, estimated using Bayesian techniques (Jaaskela J. and Nimark 2011).

The Australian economy during the past three decades experienced the 'golden age' of productivity in the first decade of the 1990s reaping the benefits of the microeconomic reforms implemented in the previous decade. During the second decade of the 2000s productivity plummeted whilst the Australian economy was riding the crest of the biggest terms-of-trade boom in its recorded history due to mining export boom powered by the demands from the growing mega Asian economies of China and India. The massive investment in the mining industries (thermal coal, iron ore and liquefied natural gas) followed the inherent phase-wise dynamics, with regards to the productivity outcomes. During the investment phase in the mining industry long lead times occurs for projects to mature or attain capacity output levels, resulting in a slump in productivity during the investment phase. Once the investment phase is completed and the mining industry attains the full production phase, productivity becomes strong. The Australian policy debate that occurred during the mining boom indicates that politicians and the media failed to understand the phase dynamics that characterised gestation lags or phase-wise dynamics that underpin mineral resource investments and this led to hyperbolic policy recommendations to boost productivity. The second important issue we have addressed in the paper relates to the monetary policy design adopted by the RBA to keep inflation within the target zone whilst the economy was riding the crest of the biggest terms- of- trade boom in its recorded history.

Although the empirics demonstrate that the Australian business cycle during the study period can be fully stylised by the RBC framework that asserts that business cycle fluctuations are caused by exogenous technological shocks, thereby rendering superfluous Keynesian type of stabilisation policies. However, we have opted to review Australian 
monetary policy during the study period using the New Keynesian framework following the New Neoclassical Synthesis. The New Keynesian theories contend that because of sticky prices and sticky wages or nominal and real rigidities frictionless markets subsumed in RBC theories do not hold sway in the short-run. Therefore, we have validated the 'triangular' version of the New Keynesian Phillips Curve (NKPC) and demonstrated that during the study period the RBA implemented monetary policy in manner that has kept inflation within the target zone, while the economy was riding the crest of the biggest terms-of-trade boom in its history. The RBA's task of achieving monetary policy stabilization goals were facilitated because Australian institutional framework comprising floating exchange rate which acted as an insulator of exogenous shocks. When the economy was subject to terms- of- trade shock the resulting real exchange rate appreciation was negated by a nominal exchange rate depreciation. Secondly, the reform of the labour markets under the Accords replaced centralized wag- fixing by productivity based enterprise bargaining, thereby preventing break out of wage inflation. In the current decade the slowdown in the mega Asian economies and oversupply in the world market for mineral resources is anticipated to exert downward pressure on the terms of trade creating formidable challenges for implementing monetary and fiscal policies to keep inflation at bay in the short-run. In the long-run the Dutch disease and deindustrialization effects have to be countermanded by implementing structural adjustment policies that will promote innovation and development of new competitive industries using the new technologies.

\section{Policy Challenges and Concluding Observations}

The policy response to the inflationary pressures arising from terms-of-trade boom cause the inflation rate to wander out of the inflation target zone of $2-3 \%$ adopted by the RBA. The policy response by the RBA that adjusts the overnight cash-rate could be analysed using the policy reaction function stylised by the Taylor's Rule (Taylor J B. 1993). If the output is above potential the output gap is positive and this would imply via the Okun law that unemployment rate is below the natural rate. This could create a scenario of inflationary pressure because the economy has hit capacity constraints and is on the brink of overheating. At this juncture the Central Bank could increase the overnight cash rate and tighten monetary policy in order to prevent the inflation genie getting out of the bottle. The Taylor rule is a policy reaction function that stylises how a Central Bank can adjust the policy rate to keep the inflation rate within the target zone. The implementation of a policy of inflation targeting using the Taylor rule type of policy reaction function avoids time-inconsistency problems that undermine policy credibility is reinforced if inflation targeting policy is implemented under the institutional framework of Central Bank independence as in contemporary Australia.

The simple Taylor's Rule capturing the thrust of the empirical results of inflation and output gap estimates reported above could take the following specification:

$$
i_{t}=i_{t}+0.5\left(\pi_{t}-\pi_{t}^{*}\right)+0.5\left(y_{t}-y_{t}^{*}\right)
$$

where,

i: cash rate or short-term interest rate.

$i^{*}=2$ per cent: long-run equilibrium interest rate.

$\pi_{t}=p_{t} \quad p_{t-4}:$ inflation rate $=\log$ difference of CPI in quarter $t$ and quarter $t-4$

$\pi_{\mathrm{t}}^{*} \log$ of target inflation rate.

$\mathrm{y}$ : $\log$ of actual real GDP, seasonally adjusted.

$\mathrm{y}_{\mathrm{t}}^{*}$ : unobserved log potential GDP.

The simple Taylor's rule specified above postulates that if the inflation rate exceeds the target rate inflation rate by $1 \%$ output could exceed potential output by $1 \%$, all else equal, In order to counteract such a rise inflation and keep the inflation rate within the target zone the cash rate should be raised by $0.5 \%$. This simple back-of-the- envelope type of calculations give some feel for the policy challenges that confront policymakers that have to take decisions using economic frameworks that have to be estimated using unobservable components using state-space modelling.

While the Taylor type policy reaction function based on the adjustment of the short-term interest rate can be used to monitor that inflation lies within the prescribed target zone while the economy is on a stable locus where the adverse effects of the productivity slump are offset by the positive income effects of the terms-of-trade due to the mining boom as in 2000 decade. In fact the Australian economy has recorded 22 years of continuous growth to date (2014) and dodged the bullet of a recession due to the global financial crisis of (2007-08) due to terms-of-trade bonanza from the mining boom and the operation of floating exchange rate, flexible labour markets and prudent financial management institutions. However, the 'salad days' due to the mining boom are showing signs of petering out as the 
the Australia is entering the 'dog days' of the post-mining boom bust since 2012 because the plummeting prices of mining exports (iron ore, coal) due a global oversupply of mining resources and a slowdown of the Chinese economy (Garnaut R. 2013)

The Australian policymakers are facing major challenges as it enters the post-mining boom era or the 'dog days':

In the short-run it has implement monetary policy using Taylor type monetary policy reaction function as discussed in the paper.

But the policymakers now face a challenge on the fiscal policy front due to the emergence of recurrent fiscal deficits and rising debt, both because of the short-fall in revenue from mining exports and increase in social welfare expenditure due to the health care and pension and superannuation funding needs. The policymakers have a formidable task of designing a monetary and fiscal policy mix that will enable the economy to keep growing whilst at the same time funding social welfare safety net payments ensuring their long-term sustainability.

In addition to crafting an optimal monetary-policy mix to keep inflation at bay and achieving sustainable fiscal deficits and debt levels, the policymakers have to undertake appropriate structural adjustment policies to tackle the 'Dutch disease' and deindustrialisation effects that have occurred due to uncompetitiveness of traditional manufacturing exports caused by the appreciation of the real exchange rate due to the mining boom. Australian manufacturing industry, particularly the motor vehicle industry has been hard hit by the dollar appreciation due to the mining boom. The closure of domestic motor vehicle manufacturing industries and the adverse multiplier effects occurring through the closure of automotive component industries demonstrates vividly the 'Dutch disease' effects of the mining boom in Australia. The manufacturing industries are the cradle of innovations and the hub of dynamic 'learning- by- doing' economies. Therefore, unless structural adjustment policies are designed to offset the adverse 'Dutch disease' effects of deindustrialisation due to the closure industries like the motor vehicle industry Australia's long-term growth and prosperity will be irrevocably impaired. The need for implementing structural adjustment policies that reskill and retrain workers to undertake jobs in the new service or information economy that could be groomed to offset the ravages of deindustrialization and Dutch disease effects of mining boom is of paramount importance to keep the Australian economy on a sustainable growth locus as discussed in (Karunaratne N D. 2013). The recent launch by the government of an agenda to promote industry Innovation and increase international competitiveness is a step in the right direction to meet the challenges of bust of the mining boom due to the fall in the value of commodity prices from their peak in 2011, leading to rising budget deficits and debt servicing burdens. The agenda identifies four key ambitions: lowering costs and establishment of business friendly environment with less red-tape, promoting international competitiveness by lowering company taxes, skilling the labour force, upgrading infrastructure, and redesigning industry policy to promote innovation and entrepreneurship. The Agenda also aims to establish new Industry Growth Centres in order to link to the new global markets and supply chains, invent and commercialise new bio-tech, nano-tech products and new services and promote them through free trade agreements (FTA) with major trading partners in the Asia-Pacific region(Australian Government 2014).

\section{References}

ABS (AUSTRALIAN BUREAU OF STATISTICS). (2012). Experimental Estimates of Industry Multifactor Productivity, Cat. 5260.0.55002.

Australian Government. (2014). Industry Innovation and Competitiveness Agenda.

Auty, R. M. (2001). Resource Abundance and Economic Development. Oxford University Press, Oxford.

Clarida, R., Gali, J., \& Gertler, M. (1999). The Science of Monetary Policy: A New Keynesian Perspective. Journal of Economic Literature, 37, p1661-1707. http://dx.doi.org/10.1257/jel.37.4.1661

Corden, W. M. (2011). The Dutch Disease in Australia: Policy Options for a Three-Speed Economy. Working Papers in Trade and Development Australian National University.

Corden, W. M., \& Neary, J. P. (1982). Booming Sector and De-Industrialization in a Small Open Economy. The Economic Journal, 92, 825-848. http://dx.doi.org/10.2307/2232670

D'Arcy, P., \& Gustafsson, L. (2012). Australian Productivity Performance and Real Incomes. RBA Bulletin, pp. 23-35.

De Brouwer, G., \& Ericsson, N. (1998). Modelling Inflation in Australia. Journal of Business and Economic Statistics, 16, 433-449.

Debelle, G., \& Vickery, J. (1998). Is the Phillips Curve a Curve ? Economic Record, 74, $384-398$. http://dx.doi.org/10.1111/j.1475-4932.1998.tb01933.x

Dolman, B., Parham, D., \& Zheng, S. (2007). Can Australia Match US Productivity Performance? Staff Working Paper Productivity Commission, Canberra. 
Durbin, I., \& Koopman, S. J. (2001). Time Series Analysis by State Space Methods. Oxford University Press, Oxford.

Eslaske, S., \& Walsh, M. (2011). Australia's Productivity Challenge. Report.

Ewing, R., Fenner, S., \& Kenndy, S, R. J. (2007). Recent Productivity Outcomes and Australia's Potential Growth. Economic Roundup (Winter 2007), pp. 49-71.

Frankel, J. A. (2010). The Natural Resource Curse: A Survey. HKS Faculty Research Working Paper Series, RWP10-005, John F. Kennedy School of Government, Harvard University.

Gali, J., \& Gertler, M. (1999). Inflation dynamics, a structural economic analysis. Journal of Monetary Economics, 44, 195-222. http://dx.doi.org/10.1016/S0304-3932(99)00023-9

Garnaut, R. (2013). Dog Days -Australia after the Boom. Penguin Books (Australia), Melbourne.

Gorden, R. J. (2003). Exploding Productivity Growth, Causes, and Implications. Brookings Papers on Economic Activity, 2, 207-298. http://dx.doi.org/10.1353/eca.2004.0006

Gordon, R. J. (1997). The Time-Varying NAIRU and its Implications for Economic Policy. The Journal of Economic Perspectives, 11, 11-32. http://dx.doi.org/10.1257/jep.11.1.11

Greogry, R. G. (1976). Some Implications of the Growth of the Mineral Sector. Australian Journal of Agricultural Economics, 20, 71-91. http://dx.doi.org/10.1111/j.1467-8489.1976.tb00178.x

Gruen, D., Pagan, A., \& Thompson, C. (1999). The Phillips Curve in Australia. Journal of Monetary Economics, 44, 223-258. http://dx.doi.org/10.1016/S0304-3932(99)00024-0

Harvey, A. (2011). Modelling the Phillips curve with unobserved components. Applied Financial Economics, 21, 7-12. http://dx.doi.org/10.1080/09603107.2011.523169

Harvey, A.C. (1989). Forecasting, Structural Time Series Models and the Kalman Filter. Cambridge University Press, Cambridge.

Hordrick, R.J., \& Prescott, E.C. (1997). Postwar US business cycles: and empirical investigation. Money, Credit and Banking., 29, 1-16. http://dx.doi.org/10.2307/2953682

Jaaskela, J., \& Nimark, K. (2011). A Medium-Scale New Keynesian Open Economy Model of Australia. The Economic Record, 87, 11-36. http://dx.doi.org/10.1111/j.1475-4932.2010.00688.x

Karunaratne, N. D. (2013). The Mining Boom, Productivity Condundrum and Monetary Policy Design to Combat Resource Curse Effects in Australia. Journal of Economics and International Finance, 6, 1-20.

Koopman, S. J., Harvey, A. C., Doornik, J. A., \& Shephard, N. (2009). Structural Time Series Analyzer, Modeller and Predictor STAMP 8.2. Tmberlake Consultants Ltd., London.

Krugman, P. (1994). The Age of Diminished Expectations, U.S. Economic Policy in the 1980s. MIT Press., Cambridge, MA.

Kydland, F.E., \& Prescott, E.C. (1982). Time to Build and Aggregate Fluctuations. Econometrica, 50, 1345-1370. http://dx.doi.org/10.2307/1913386

Lucas, R.E. Jr., \& Sargent, T. (1978). After Keynesian macroeconomics, in After the Phillips Curve: Persistence of High Unemployment and High Inflation, Conference Series 19, Federal Reserve Bank of Boston.

Okun, A. M. (1962). Potential, GNP: Its Measurement and Significance, Paper Presented at the American Statistical Association Proceedings of the Business Section.

Porter, M. (1991). The Competitive Advantage of Nations. The Free Press, New York.

Rahaman, J., Stephen, D., \& Tunny, G. (2009). Estimating Trends in Australia's Productivity. Treasury Working Paper 2009-01 (February).

Sachs, J. D., \& Warner, A. M. (2001). The Curse of Natural Resources. European Economic Review, 45, 827-838. http://dx.doi.org/10.1016/S0014-2921(01)00125-8

Solow, R. (1957). Technical Change and Aggregate Production Function. Review of Economics and Statistics, 39, 312-320. http://dx.doi.org/10.2307/1926047

Stevens, G. (2010). The Challenge of Prosperity. Address to the Committee for Economic Development (CEDA), Melbourne 29 November.

Stevens, G. (2011). Economic Conditions and Prospects. RBA Bulletin, pp. 83-88.

Sturm, M., Gurtner, F., \& Alegre, J.G. (2009). Fiscal policy challenges in oil-exporting countries a review of key issues. European Central Bank, Occasional Paper Series no 104. 
Taylor, J. B. (1993). Discretion versus Policy Rules in Practice. Carnegie-Rochester Conference Series in Public Policy, 195-214. http://dx.doi.org/10.1016/0167-2231(93)90009-L

The Economist. (1977). The Dutch Disease. The Economist, November 26, 82-83.

The Parliamentary Inquiry. (2010). The Parliament of the Commonwealth of Australia. Inquiry into raising the productivity growth rate in the Australian economy. Report, Canberra.

Topp, V., Soames, L., Parnham, D., \& Bloch, H. (2008). Productivity in Mining Industry: Measurement and Interpretation. Productivity Commission Staff Working Paper. Commonwealth of Australia.

Treasury. (2007). Intergenerational Report 2007. Report, Canberra.

\begin{tabular}{|c|c|}
\hline \multicolumn{2}{|c|}{ ACRONYMS } \\
\hline $\mathrm{ABS}$ & Australian Bureau of Statistics \\
\hline AIC & Akaike Information Criterion \\
\hline AR & Autoregression \\
\hline CPI & Consumer Price Index \\
\hline DW & Durbin Watson \\
\hline GDP & Gross Domestic Product \\
\hline GFC & Global Financial Crisis \\
\hline GFC & Global Financial Crisis \\
\hline $\mathrm{HPF}$ & Hordrick Prescott Filter \\
\hline $\mathrm{KF}$ & Kalman Filter \\
\hline LP & Labour Productivity \\
\hline MFP & Multifactor Productivity \\
\hline NKPC & New Keynesian Phillips Curve \\
\hline PC & Productivity Commission \\
\hline RBA & Reserve Bank of Australia \\
\hline RW & Random Walk \\
\hline $\mathrm{SIC}$ & Schwarz Information Criterion \\
\hline SS & State Space \\
\hline TFP & Total Factor Productivity \\
\hline TOT & Terms of Trade \\
\hline $\mathrm{UC}$ & Unobserved Components \\
\hline UNE & Unemployment Rate \\
\hline
\end{tabular}

\section{Notes}

Note 1. Hordrick- Prescott Filter or HP-Filter

The HP-Filter assumes that the log of time-series yt consist of a trend component notated by a superscript $*$ over the series and a cyclical component. It the en minimizes the loss function L that consists of the weighted sum of squared deviation of the actual value of the variable from its trend plus the squared deviation of the growth rate of the trend from its potential growth rate weighted by the smoothing parameter $\lambda$ as specified below:

$$
\operatorname{Min} \mathrm{L}=\sum\left(y_{t}-y^{*}\right)^{2}+\lambda \sum\left(\Delta y_{t}-\Delta y^{*}\right)^{2}
$$

The larger the value of $\lambda$ the smoother the trend becomes. In the estimation of trend or potential output we have 
assumed the smoothing parameter to $\lambda=32$ following Gordon (1983) while Hordrick and Prescott assumed $\lambda=1600$ to estimate trends from quarterly data.

In the smooth version of the local linear trend model by selecting the level fixed, slope stochastic and irregular for components the HP filter can be replicated by assuming

$\sigma_{\eta}^{2}=0$ and $\sigma^{2} \zeta=1 / 32$ for the Gordon filter and $\sigma^{2} \zeta^{2}=1 / 1600$ for the HP filter (Harvey and Jaeger 1993). .

Note 2. Cobb-Douglas Production Function

The Solow-Swan Growth Accounting methodology is based on the Cobb-Douglas production function, which the simplest specification of the neoclassical production function. Others being the Translog, CES production functions. In the Cobb-Douglas production function GDP $\left(\mathrm{Y}_{\mathrm{t}}\right)$ is assumed to be a function of technological progress or MFP measured by $(A)$ and inputs of factors capital $\left(K_{t}\right)$ and labour $\left(L_{t}\right)$ weighted by share output given by $(\alpha)$ and $(1-\alpha)$ for $K_{t}$ and $L_{t}$, respectively. The production function is specified assuming constant returns to scale and Hicks-neutral technical progress (which implies that there is no factor substitution as the production function shifts. The Cobb-Douglas production function is specified by.

$$
Y_{t}=A_{t} K_{t}{ }^{\alpha} L_{t}(1-\alpha) "
$$

Log-linearizing the above production function and re-arranging the residual term (A) which is the measure of MFP and technical progress can be obtained as shown below, where the lower case letters refer to logs of the variables:

$$
a=y_{t}-\alpha k_{t}+(1-\alpha) l_{t}
$$

The MFP series recently published by the ABS and used in this study is based on the Translog version of the neoclassical production function.

Note 3. State Space Form (SSF)

The unobservable components given in a time series $y_{t}$ can be decomposed into the sum of a permanent $\left(y+t^{p}\right)$ and transitory component $\left(\mathrm{z}_{\mathrm{t}}\right)$ that can correspond potential output and the output gap respectively, as hypothesized by Watson (1986) yielding:

$$
y_{t}=y_{t}^{p}+z_{t}
$$

Further potential or permanent output is assumed to follow random walk with $\operatorname{drift}\left(\mu^{\curlyvee}\right)$ :

$$
y_{t}^{p}=\mu^{y}+y_{t-1}^{p}+\varepsilon_{t}^{y} \text { where } \varepsilon_{t}^{y} \sim N\left(0, \sigma_{y}^{2}\right)
$$

and the output gap $\left(\mathrm{z}_{\mathrm{t}}\right)$ is assumed to follow an autoregressive process order two or $\operatorname{AR}(2)$ :

$$
z_{t}=\emptyset_{1} z_{t-1}+\emptyset_{2} z_{t-2}+\varepsilon_{t}^{Z} \text { where } \varepsilon_{t}^{Z} \sim N\left(0, \sigma_{y}^{2}\right) \text { so that stationarity holds. }
$$

Using the terminology of(Harvey A. 2011) have transformed the above observation and state equations into the State Space Form (SSF) to facilitate the estimation of the maximum likelihood estimates of the parameters by applying the Kalman Filter as explained in(Harvey A.C. 1989)

In the specification of the SSF the observed variables yt are related to a set of unobserved state variables state variables $\alpha$ that could for example, include the trend growth rate, permanent output and the output gap. The measurement or observation equation defines the evolution of the observed variables in terms of the unobserved state variables thus:

$$
y_{t}=Z \alpha_{t}+d_{t}+S \varepsilon_{t}
$$

where $\mathrm{T}$ : is a matrix of coefficients, $\mathrm{c}$ : is a matrix of exogenous variables and $\varepsilon$ : is a vector of white-noise disturbance terms weighted by $\mathrm{S}$. The transition or state equations specified below describes the time-series process governing the evolution of the unobserved state variables over time:

$$
\alpha_{t}=T \alpha_{t-1}+c_{t}+\eta \varepsilon_{t}
$$

Once transformed into the SS form, the Kalman Filter can be applied to estimate the maximum likelihood estimates of the parameters of the model and the observed state variables by maximizing the following likelihood function given below:

$$
\log \Lambda=-(N S / 2) \log 2 \pi-\sum_{t=1}^{S} \log \mid F_{t} / 2-\sum_{t=1}^{S} v_{t}^{\prime} F_{t}^{-1} v
$$

Where $\mathrm{N}$ : is the number of observed variables, $\mathrm{S}$ : the sample size, $v$ : is the prediction error matrix, $\mathrm{F}$ : is the mean square error matrix for prediction errors. 
The resultant estimate is a univariate decomposition of the output gap and this equation can be extended to include information about the output gap contained in the Phillip's curve, where inflation is below the expected level if output gap is negative

The KF is a mechanical procedure that updates the equations by filtering and smoothing explained in (Harvey A.C. 1989, Durbin I and Koopman S J. 2001)

Note 3 on State Space (SS) Modelling.

Trend plus Cycle Model and Cyclic Trend Models linking MFP and GDP.

The statistical specification of a deterministic cycle $\psi t$ is given below:

Where $\lambda_{\mathrm{t}}$ : frequency in radians in the range $(0$ to $\pi), \kappa_{t}$ and $\kappa_{t}^{*}$ serially uncorrelated white-noise disturbance terms with mean zero and common variance $\sigma^{2}{ }_{\mathrm{K}}$ and a damping factor $\rho$. The cycle $\Psi_{\mathrm{t}}$, can be written in a single equation where $\mathrm{L}$ is the lag operator:

$$
\left.\Psi_{t}=\mu_{t}+\left[\left(1-\rho \cos \lambda_{c} L\right) \kappa_{t}+\rho \sin \lambda_{c} L\right) \kappa_{t}^{*}\right] /\left(1-2 \rho \cos \lambda_{c} L+\rho^{2} L^{2}\right)+\varepsilon t .
$$

The above cycle becomes first order autoregressive process or an $\operatorname{AR}(1)$ when $\lambda_{c}=0$ or $\pi$. If the damping factor $\rho=1$ the above cycle becomes an $\operatorname{ARMA}(2,1)$ and ollapses to an $\operatorname{AR}(2)$ when $\sigma^{2}{ }_{k}=0$.

The parameters in the Cycle plus Trend Model specified above are:

$\sigma^{2}$ : the variance that makes the cycle stochastic.

$2 \pi / \lambda_{t}:$ the period of the cycle measured in years.

$\pi / \lambda_{c}$ : the frequency of the cycle

$\rho$ : the damping factor.

The bivariate version of the Cyclic Trend Model could be used to jointly estimate the relationship between $y_{t}=M_{F}$ and $\mathrm{x}_{\mathrm{t}}=\mathrm{GDP}$ rather than estimating each component separately using the bivariate specification given below:

$$
\left[\begin{array}{l}
y_{t} \\
x_{t}
\end{array}\right]=\left[\begin{array}{l}
\mu_{t}^{y} \\
\mu_{t}^{x}
\end{array}\right]+\left[\begin{array}{l}
\psi_{t}^{y} \\
\psi_{t}^{x}
\end{array}\right]+\left[\begin{array}{c}
\varepsilon_{t}^{y} \\
\varepsilon_{t}^{x}
\end{array}\right]
$$

Note 4. Diagnostic tests

Most of th diagnostic tests referred to below are cited in (Koopman S J Harvey A C Doornik J A and Shephard N. 2009) and are computed from the residuals of a correctly specified model.

High residual autocorrelations of order $\tau$ measured by $r_{t}(\tau)$ indicates that the fitted model fails to capture the dynamics of the model adequately. The Box-Ljung (1978) portmanteau test for the significance of the null of $p$ autocorrelations is distributed like a Chi-squared with $(q)$ degrees of freedom as summarised by $Q(p, q) \sim \chi^{2}(q$ d.f.). The test for heterosekdasticity defined by $\mathrm{H}(\mathrm{h})$ is the ratio of the squares of the last $\mathrm{h}$ residuals to that of the first $\mathrm{h}$ residuals, where $\mathrm{h}$ is the closest integer to $\mathrm{T} / 3$ and is distributed like an $\mathrm{F}$ distribution with $\mathrm{h}, \mathrm{h}$ degrees of freedom i.e. $\mathrm{h} \sim \mathrm{F}_{\mathrm{h}, \mathrm{h} \text { d.f., }}$, where a high(low) value indicates an increase(decrease) of variance over time. The test for normality (NORM) is the Bowman and Shenton (1975) computed from the ratio of third to fourth moments of the residuals is distributed like a Chi-squared with 2 d.f. i.e. $\sim \chi^{2}{ }_{2 \text { d.f.) }}$ with a critical value of 5.99 for at the $5 \%$ level of significance.

Measures-of-goodness-of-fit

Measures of goodness- of- fit are provided by the prediction error variance (PEV).which is based on one-step-ahead errors in the steady state and is equal to the square root of the standard error (Std. Error) of the fitted equation. The measure of goodness-of-fit given by the coefficient of determination $\left(R^{2}\right)$ indicates that fitted model is superior to a random-walk model with drift if $0<\mathrm{R}_{\mathrm{D}}^{2} \leq 1$ and inferior to the random walk with drift model if $\mathrm{R}_{\mathrm{D}}^{2} \leq 0$.

Furthermore, the minimum value of the Akaike Information Criterion (AIC) and the Bayesian Information (BIC) are also useful information criteria to compare the goodness-of-fit of models with different parameters. A detailed exposition of the diagnostic tests and goodness-of-fit criteria that have been used above are explained in STAMP 8.2 (Koopman S J Harvey A C Doornik J A and Shephard N. 2009). 